\title{
Design of Chip Conveyor
}

\author{
K. SZABO. \\ University of Miskolc, Faculty of Mechanical Engineering and Informatics, Department of Machine Tools, \\ szgtszab@gmail.com
}

Abstract. The following article examines the design methodology of screw conveyors. The most significant steps are discussed concerning the design of the apparatus and its use in machine tools as a service component is explained.

\section{Introduction}

Nowadays a drastic increase can be perceived in the operation of the production tools, so the automation of machining processes requires that the auxiliary processes should be performed automatically by structural units and equipment without any direct human intervention [1][2]. Screw handling unit is one of the most used machines with continuous operation with some theoretical questions from János Benkő and Sándor Verdes [3][4]. The University of Miskolc, Faculty of Mechanical Engineering and Information Technology boasts a wealth of knowledge in the design methodology of various machines and equipment that was utilized in this topic [5][6][7][8][9].

\section{Designing process}

\subsection{Determination of boundary conditions}

The determination of boundary conditions is necessary to start the design phase of the system. The amount of material separated by the machine was determined based on the performance of the milling machine and the maximum applicable size of the tool. During the calculations the maximum allowable cutting speed and feed rate were counted. By the multiplication of the amount of separated material by the volumetric factor of the chip, the volumetric flow rate of the actual chip volume to be discharged in one minute was obtained. In the case of milling machines, the chip is characterized by a screw, a spiral or a fragmented shape with a volumetric factor of from 3 to 25 [10]. In the design phase the calculations were executed by the application of the highest value. The bulk density of the transported material was determined as it is required to be known to be able to calculate the transport capacity in terms of [tonne per hour].

\subsubsection{Geometric scaling}

In case of screw conveyors, the geometric scaling of the screw could be determined based on formulas for the determination of the expected transport capacity and maximum speed [11], which could be described as: 


$$
D=\sqrt[5]{\left[\frac{240 Q}{3,6 \pi\left(\frac{S}{D}\right) \rho_{h} \varnothing}\right]^{2} \frac{\mu}{2 g 9,55^{2}\left[\cos \delta \sqrt{\mu^{2}+1}+\sin \delta \operatorname{tg}(\alpha+\rho)\right]}}
$$

The " $\mathrm{D}$ " parameter in the equation is the nominal diameter of the screw in meters, the "Q" in the transport capacity ton / hour, the "n" the rev of the worm shaft per minute, the "s" the pitch of the screw spiral in meters, " $\rho_{\mathrm{h}}$ " the bulk density in $\mathrm{kg} / \mathrm{m}^{3}$, " $\Phi$ " filling factor, "g" acceleration due to gravity $\mathrm{m} / \mathrm{s}^{2}$, " $\mu$ " coefficient of friction, " $\delta$ " is the inclination angle of the transport direction in degrees, " $\rho$ " is the angle of friction expressed in degrees, " $\alpha$ " is the pitch angle in degrees, and "s/D" is a standard value. The diameter obtained is the same as the minimum diameter of the screw, which must be multiplied by the safety factor. The obtained result was rounded up to a standard value. By knowing the diameter of the screw conveyor, the minimum speed was calculated as a function of the expected capacity. Being able to determine the proper operating parameters of the material handling unit, the maximum transport capacity at maximum speed should be calculated.

\subsubsection{Design of body parts}

In case of the design of the body elements, where it was important to seek the proper shaping of the bearing and fixing points, the mechanical connections to the bed were designed at the first step. It was investigated and identified where the material should be counted, as suitable collecting elements should be placed at the right points. If the purpose is the transportation and separation of materials with different consistency, the appropriate design solutions should be provided to ensure that these functions can be performed during machine operation. A well-designed chamber at the material transfer points was created in order to ensure the smooth flow of the process. Suitable structural elements were provided for connection to geared motors and ancillary components. The appropriate filtration and collection of the separated liquids was guaranteed by means of a container. Being aware of the structural elements formed, the resulting geometrical and different connection dimensions could be determined. Based on the previous correlation, it is possible to determine the required length of the auger rows.

\subsubsection{Selection of standard elements}

In the following phase standard parts could be selected, like bearings for geared motors and clutches. In terms of bearing, it is advisable to select from the range of pre-assembled bearing units, however, where the bearings are surrounded by flowing material, it is preferable to choose a plain bearing to utilize the advantageous installation dimensions. In order to achieve proper operation, in the case of the motors with worm geared motors, it is advisable to select the low speed and high torque. When selecting the clutch, care must be taken to be able to transfer the power of the drive motor when coupling long axes to be able to tolerate angular defects and reduce harmful dynamic effects. 


\section{Control}

The control of the parts is necessary as it demonstrates whether the parts have been selected correctly. The motors are checked based on the power required to drive each auger line, which depends on static and dynamic loads. The material part added to the trough was considered to be a mass point, and it was assumed that the mass point moves on the surface of the screw base and on the helical edge of the auger, and the factors of friction can be considered to be constant. Thus, starting from the differential equation of the mass point moving on the helical axis [3], the components of forces acting in each direction could be determined as follows:

$$
\begin{gathered}
K_{x}=-N \cos \varphi+B \sin \alpha \sin \varphi \\
K_{y}=-N \sin \varphi-B \sin \alpha \cos \varphi \\
K_{z}=B \cos \alpha
\end{gathered}
$$

Where " $\mathrm{N}$ " is the force of the trough wall, "B" is the force exerted on the helical, and " $\varphi$ " is the angle of rotation of the quasi-permanent state. In addition to the weight of the screw, the bearings are loaded by the same forces as " $\mathrm{N}$ " and "B", but the direction is its opposite, so the radial bearing load is:

$$
F_{r}=\sqrt{(N \cos \varphi-B \sin \alpha \sin \varphi)^{2}+\left(N \sin \varphi+B \sin \alpha \cos \varphi+G_{c \operatorname{siga}} \cos \delta\right)^{2}}
$$

Using the parameters defined so far in Equation (2), (3) and (4), the performance which is required to move the material can be determined.

$$
P_{1}=c\left[K_{x} v_{x}+K_{y} v_{y}+K_{z} v_{z}\right]
$$

In the case of the nearly horizontal conveyors, only the z-direction velocity component is not zero, and "c" is a factor that takes internal resistances into account. Determination of the performance requirement of friction:

$$
P_{2}=\frac{d}{2} \omega\left(\mu_{t} F_{z}+\mu_{r} F_{r}\right)
$$

Where " $\mathrm{d}$ " stands for the axis diameter, " $\omega$ " the circular frequency, " $\mu_{\mathrm{t}}$ " is the axial bearing factor of friction, " $F_{z}$ " is the axial load force, " $\mu_{r}$ " is the radial bearing factor of friction and " $F_{r}$ " is the radial load value.

The power required to overcome the acceleration resistance plays a role when the material needs to be accelerated from zero, determined by equation (8).

$$
P_{3}=Q_{\max } v^{2}
$$

In the equation " $\mathrm{Q}_{\max }$ " is the maximum transport capacity and " $\mathrm{v}$ " is the speed. Based on all the results of the previous calculations, all performance can be calculated as follows:

$$
P_{\text {all }}=c^{\prime} \frac{P_{1}+P_{2}+P_{3}}{\eta}=[W]
$$


In the equation "c" is the safety factor and " $\eta$ " is the efficiency of the drive. The motors are suitable if their rated power is greater than the power requirement of the screw. The selected clutches were checked at the maximum permissible torque [12]. For plain bearings, the check was based on permissible surface pressure [13].
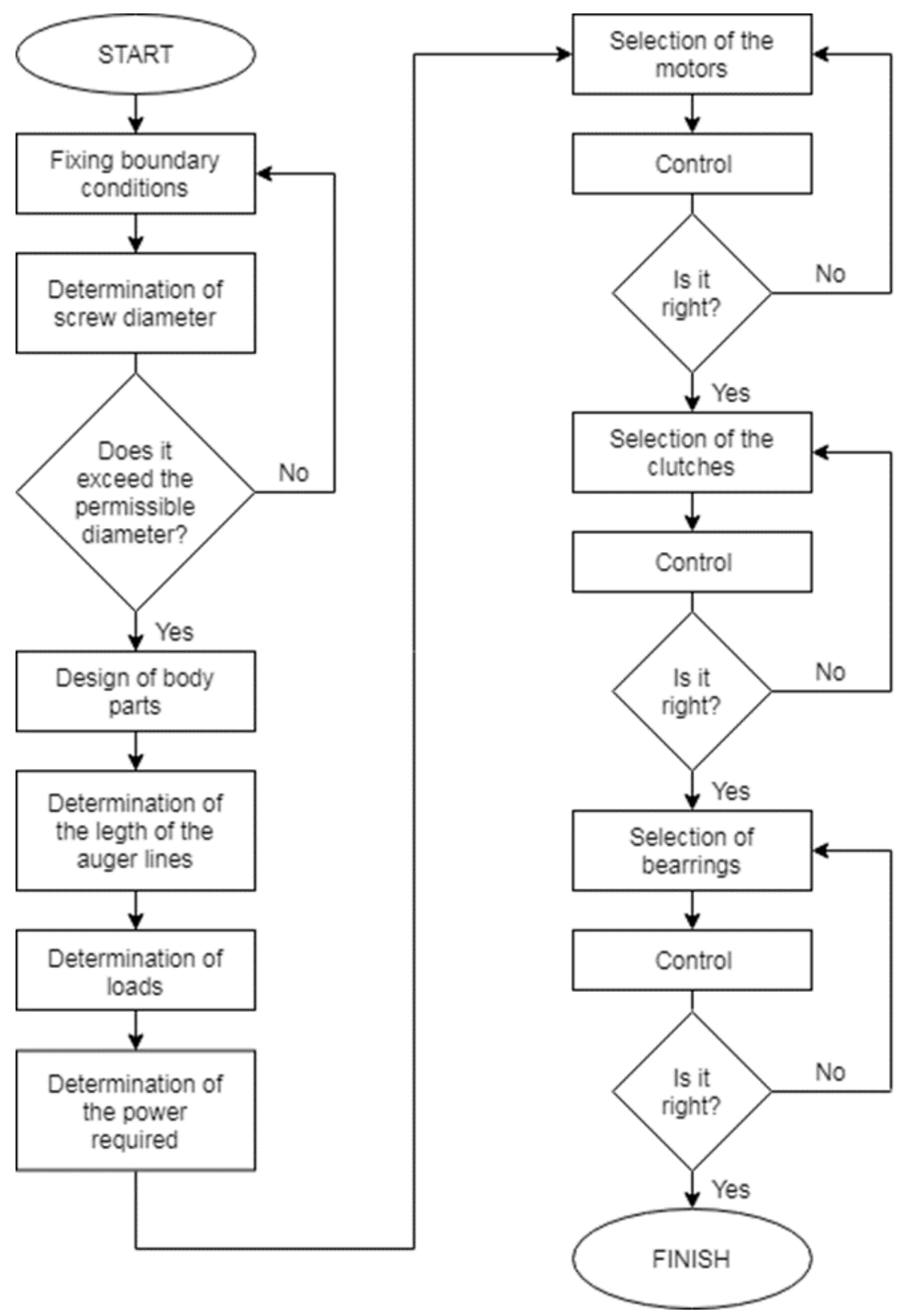

Figure 1. Applied designing method.

The applied designing method, which is shown in Figure 1, can be successfully used to define the geometric scaling and designing of screw conveyors. Based on the developed dimensions, the method 
can be used to accurately determine the static and dynamic loads of the auger lines, which can be used to select and check commercially available standard parts.

\section{Acknowledgments}

The described article was carried out as part of the EFOP-3.6.1-16-00011 "Younger and Renewing University - Innovative Knowledge City - institutional development of the University of Miskolc aiming at intelligent specialisation" project implemented in the framework of the Szechenyi 2020 program. The realization of this project is supported by the European Union, co-financed by the European Social Fund.

\section{References}

[1] Ch. Bührdel, - G. Frömmer (1984) Automata forgácsoló szerszámgépek, Műszaki Könyvkiadó.

[2] Takács, Gy. - Szilágyi, A. - Demeter, P. - Barak, A. (2009) Forgácsoló szerszámgépek, Nemzeti Tankönyvkiadó

[3] Benkő, J. (1994) A szállítócsigák néhány elméleti kérdése, Gépgyártástechnológia, XXXIV (78). pp. 274-282. ISSN 0016-8580

[4] Verdes, S. (2012) Anyagmozgatás és gépei, Pannon Egyetem

[5] Szombatfalvy, Á. (1981) Szerkezeti elemek tervezésének technológiai szempontjai, Műszaki Könyvkiadó, Budapest

[6] Hegedűs, Gy. (2002) A módszeres géptervezés alkalmazása ipari mérőgép fejlesztése estén, Doktoranduszok Fóruma 2002: Gépészmérnöki Kar szekciókiadványa.

[7] Kamondi, L. - Sarka, F. - Takács, Á. (2011) Fejlesztés- módszertani ismeretek, Nemzeti Tankönyvkiadó, Miskolc

[8] G. Pahl, W. Beitz, J. Feldhusen, K. - H. Grote (2007) Engineering Design - A Systematic Approach, London: Springer-Verlag, ISBN 978-1-84628-318-5

[9] Takács, Gy. - Zsiga, Z. - Szabóné Makó, I. - Hegedűs Gy. (2011) Gyártóeszközök módszeres tervezése, Nemzeti Tankönyvkidó, Miskolc

[10] Kulcsár, T. (2012) Gépipari technológiai ismeretek, Pannon Egyetem

[11] Benkő, J. - Nagy, Z. (2013) Tervezési segédlet szállítócsigákhoz, Szent István Egyetem, Gödöllő

[12] Németh, G. (2013) Biztonsági tengelykapcsoló méretezése (Oktatási segédlet), Miskolci Egyetem, Miskolc

[13] Péter, J. (2008) Géptervezés alapjai, Miskolci Egyetemi Kiadó, Miskolc-Egyetemváros, 402 old. ISBN 978-963-661-837-7 